\title{
Effects of Fuel Additives on Performance and Emission Characteristics of Spark Ignition Engine
}

\author{
A. Adebayo and O. Awogbemi
}

\begin{abstract}
This research investigated the effects of addition of ethanol to gasoline with the aim of improving the performance and emission characteristics of Spark Ignition (SI) engine. Four samples of gasoline-ethanol blend were prepared, namely $100 \%$ ethanol, $100 \%$ gasoline, $95 \%$ gasoline $+5 \%$ ethanol and $90 \%$ gasoline $+10 \%$ ethanol, and were labeled sample A, B, C and D respectively. Physicochemical analysis was carried out on the four samples while sample $B, C$, and $D$ were used to run a single cylinder, two stroke, air cooled SI engine to determine the performance characteristics of the engine at four engine speeds of 800rpm, 1000rpm, 1200rpm, and 1400rpm. An exhaust gas analyzer was used to analyze the exhaust emission to determine its constituents at no load. The research concluded that blending gasoline with ethanol not only improved the performance of the engine, it also yielded a friendlier emission. It also solves the problem of sole dependence on petroleum products to run SI engines with its attendant cost and environmental implications.
\end{abstract}

Index Terms-Ethanol; Gasoline; Spark Ignition; Emission; Performance.

\section{INTRODUCTION}

The modern society, driven by technology, faces the challenges posed by increased environmental pollution from Internal Combustion Engines (ICE) emissions. The effects of these emitted pollutants are not limited to hazards such as global warming, acid rain, smog, and respiratory and other health problems. To make the environment sustainable, it is necessary to reduce the harmful emissions. The prominent emissions from ICEs, such as $\mathrm{HC}, \mathrm{CO}, \mathrm{NO}_{\mathrm{x}}, \mathrm{SO}_{2}$, and solid particles can be reduced by the addition of appropriate additives to the fuel while also increasing the vehicle performance. Alcohol is one of the fuel additives that can achieve both. Alcohol (methanol or ethanol) has a good antiknock characteristic, it is a renewable energy source and can reduce $\mathrm{CO}$ and $\mathrm{HC}$ emissions. However, ethanol is preferable to methanol because of its less toxicity, flammability and oxygenated characteristics. These qualities bring about improved fuel properties when compared to gasoline. Besides, the higher auto-ignition temperature and flash point of ethanol, the lower Reid evaporation pressure and the lower evaporative losses make it safer for transportation and storage. Ethanol has been found to have higher latent heat of evaporation, allows lower intake manifold temperature,

Published on March 23, 2017.

A. Adebayo is with Mechanical Engineering Department, Ekiti State University, Ado Ekiti, Nigeria. (e-mail: yka615@yahoo.com).

O. Awogbemi is with Mechanical Engineering Department, Ekiti State University, Ado Ekiti, Nigeria. (e-mail: jolawogbemi@yahoo.com). results in increased volumetric efficiency, contains more oxygen that help to achieve complete combustion than gasoline. In spite of these advantages, ethanol usage as fuel has not been fully embraced [1].

\section{LITERATURE REVIEW}

Many researchers [2], [3], [4] have investigated the effects of various alternative fuels on the performance and the degree of emission of harmful gases of an engine with various level of success and results. In a research, various blends of ethanolgasoline fuels were used in engine tests, the outcome of this study show that the inclusion of $10 \%$ ethanol has a significant effect on the octane number by $5 \%$ and also the engine power output was however increased.

Abdel- Rahman and Osman also tested various percentages of ethanol blends in a variable-compression-ratio engine. They found that increase in ethanol content in the fuel blend caused an upsurge in the octane number, however, this would bring about a decreases in the heating rate. The increase of $10 \%$ in the addition of ethanol shows a noticeable result on the rise in the octane number. However, further down several compression ratios of engine, the optimum mixing ratio, without engine modification, for ethanol/gasoline was showed to be $10 / 90 \%$ [6]. Blending gasoline with ethanol has also been found to reduce $\mathrm{Co}$ and UHC emissions in engines [7].

In a research on the effects of ethanol-unleaded gasoline blends on engine performance and exhaust emission in SI engine. The results of this research indicated that the inclusion of unleaded gasoline gives rise to the increase in the engine torque, this also increases the fuel consumption, and power. However, there is a reduction in the emissions of hydrocarbon, carbon monoxide and nitrogen oxide. The result also showed that the ethanol-gasoline blends resulted in increase in compression ratio [8].

\section{MethodOLOGY}

Four samples (A-D) were prepared and used for this research. These were 100\% ethanol, 100\% gasoline, 95\% gasoline blended with 5\% ethanol, and $90 \%$ ethanol blended with10\% ethanol and were labeled as samples A, B, C and D respectively. Ethanol was purchased from open market with 95\% concentration while gasoline was gotten from the Nigerian National Petroleum Corporation (NNPC) retail outlet in Ado Ekiti, Nigeria. The four samples (A, B, C, D) were subjected to standard laboratory analysis to determine the physicochemical fuel properties. However, only samples B, C, 
and $\mathrm{D}$ were used for the engine performance tests because spark ignition engines cannot be run on $100 \%$ ethanol.

Standard laboratory methods were adopted to determine the refractive index, specific gravity, kinematic viscosity, ash content, flash point, volatile matter, cloud point, pour point, fire point, moisture content, fixed carbon, boiling point and heating value of the fuel samples. Samples B, C, and D were used to run a single cylinder, Spark Ignition, small ICE test bed to determine its performance characteristics while an exhaust gas analyzer was used to analyze the exhaust gases at different engine speeds.

\section{A. Experimental Set Up}

The TD200 small engine experiment was conducted to validate the fuel additives of the analysis and to implement strategies for fuel additive start ability and control. The TD200 small engine is a $200 \mathrm{cc}$ two stroke, air-cooled single cylinder
SI engine loaded by a hydraulic dynamometer. The hydraulic dynamometer is used to apply load to the test engine. The test engine fits to the bed in line with dynamometer and coupled to a shaft by means of a small flexible coupling. The test engine was attached to an hydraulic dynamometer equipped with a device control panel fixed with a torque gauge, switches for the load remote control and electric tachometer. With the aid of a stopwatch with a standardized burette, the consumption of the fuel was however measured. The experiments were conducted at four engine speeds of $800 \mathrm{rpm}, 1000 \mathrm{rpm}$, $1200 \mathrm{rpm}$ and 1400rpm using the fuel samples B, C, and D. An exhaust gas analyzer was connected to analyze the constituents of the exhaust gas during the course of the experiment. Figs. 1, 2 and 3 show the engine test bed, and the exhaust gas analyzer, and the front view of the exhaust gas analyzer respectively.

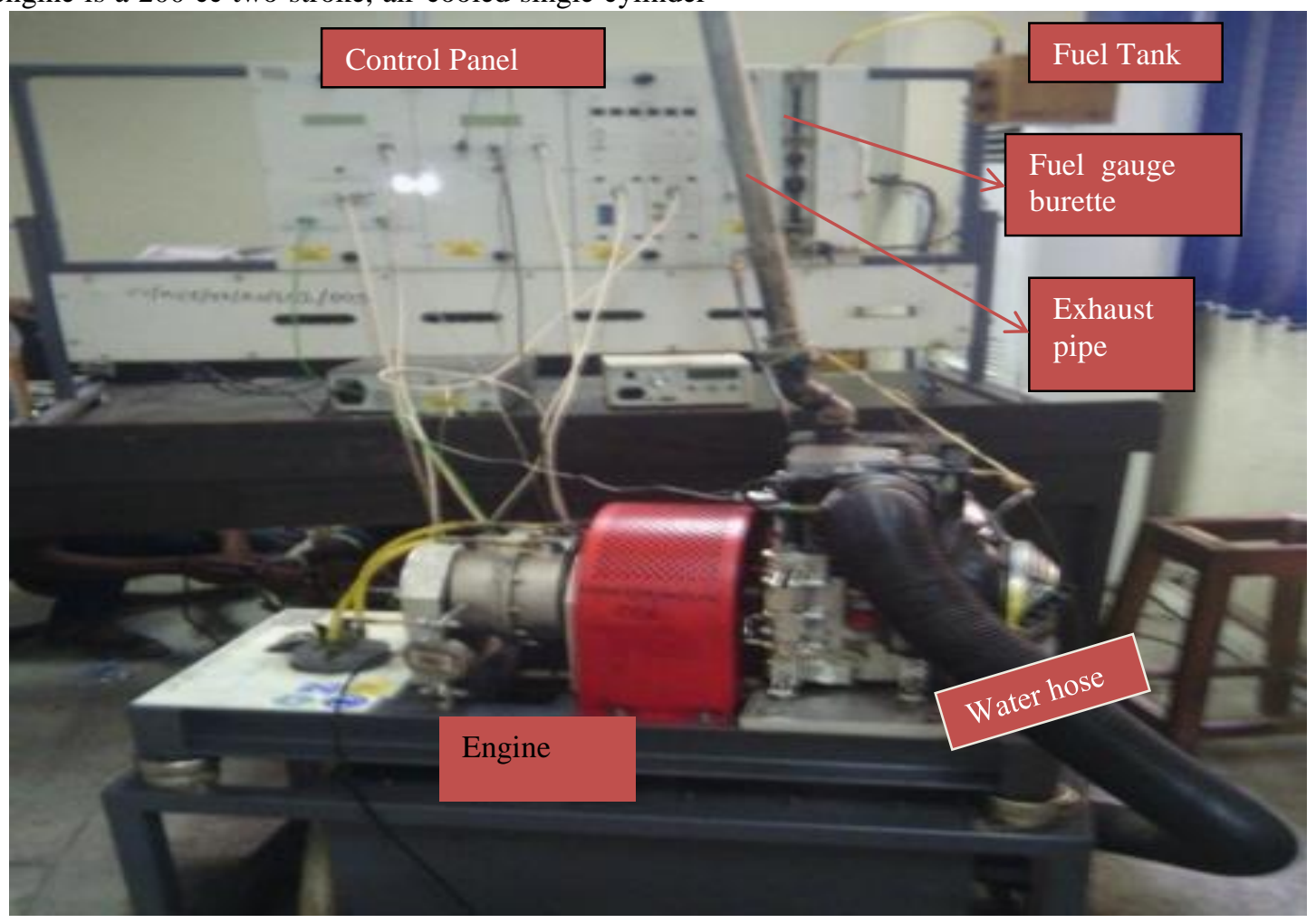

Fig. 1.The Engine test bed 


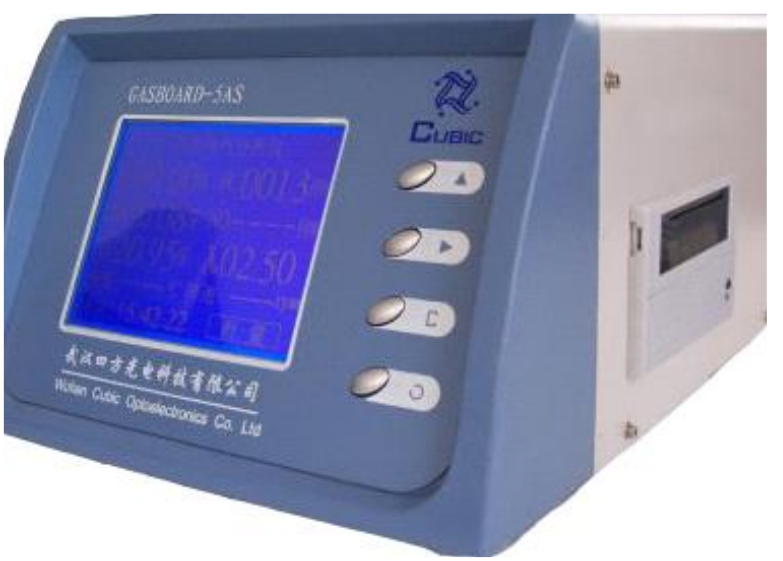

Fig. 2. Exhaust Gas Analyzer

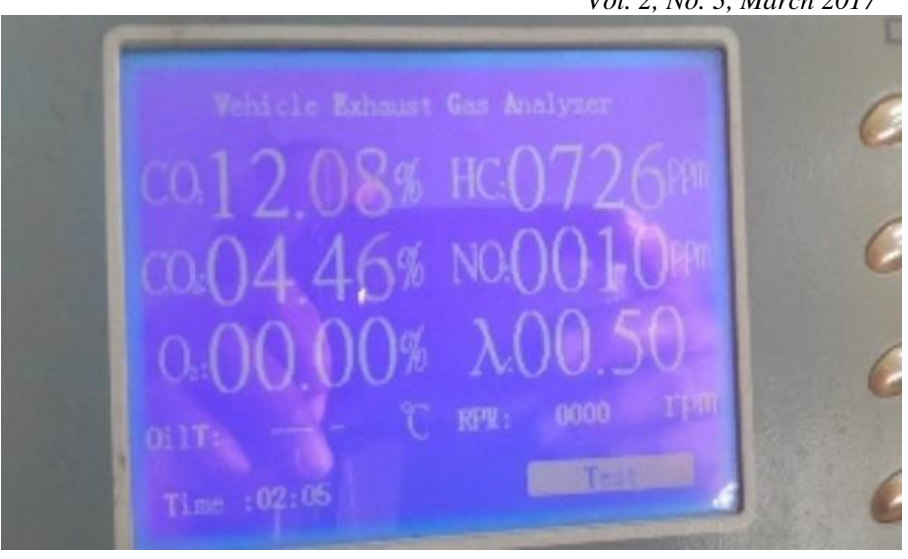

Fig. 3. Front view of the Exhaust Gas Analyzer

\section{A. Physiochemical Result}

The physiochemical tests were carried at Federal University of Technology, Akure, Nigeria. The results of the analysis are shown in Table I. namely the physiochemical result, engine performance results, and emission test result.

TABLE I: THE Results OF THE PHysicochemicAl ANALYSIS OF SAMPLES

\begin{tabular}{lllll}
\hline \hline Parameter & Sample A & Sample B & Sample C & Sample D \\
\hline Refractive index $@ 30^{\circ} \mathrm{C}$ & 1.360 & 1.452 & 1.423 & 1.423 \\
Specific gravity $\left(\mathrm{g} / \mathrm{cm}^{3}\right)$ & 0.7756 & 0.7043 & 0.7029 & 0.7040 \\
Kinematic Viscosity (pas/sec) & $1.7690 \times 10^{-3}$ & $0.8498 \times 10^{-3}$ & $0.8150 \times 10^{-3}$ & $0.8456 \times 10^{-3}$ \\
Ash content $(\%)$ & 0.011 & 0.003 & 0.071 & 0.073 \\
Flashpoint $\left({ }^{\circ} \mathrm{C}\right.$ & 54 & 33 & 42 & 42 \\
Volatile matter $(\%)$ & 94.144 & 99.666 & 97.198 & 90.983 \\
Cloud point $\left({ }^{\circ} \mathrm{C}\right)$ & -10 & -16 & -10 & -12 \\
Pour point $\left({ }^{\circ} \mathrm{C}\right)$ & 8 & -2 & -6 & -5 \\
Fire point $\left({ }^{\circ} \mathrm{C}\right)$ & 68 & 33 & 42 & 42 \\
Moisture content $(\%)$ & 1.860 & 1.876 & 1.871 & 2.027 \\
Fixed carbon $(\%)$ & 0.985 & 0.291 & 0.860 & 6.917 \\
Boiling point $\left({ }^{\circ} \mathrm{C}\right)$ & 78 & 38 & 42 & 44 \\
Heating value $(\mathrm{kJ})$ & 33210.91 & 33482.434 & 32555.886 & 32848.938 \\
\hline \hline
\end{tabular}

Key: Sample A = 100\%Ethanol, Sample B = 100\% Gasoline, Sample C = 95\% Gasoline + 5\%Ethanol, Sample D = 90\% Gasoline + 10\% Ethanol

As shown in Table I, the physicochemical properties of the physicochemical properties of sample A (ethanol) like boiling point, fire point, flash point, specific gravity, cloud point, fixed carbon, etc., were found to be higher than that of sample $\mathrm{B}$ (gasoline). This may be due to the make-up of ethanol which makes it require more energy for combustion when compared with gasoline. However, the heating value of gasoline was found to be greater than that of ethanol which shows that more energy is derived from the combustion of equal volume of gasoline than ethanol.

Also samples $\mathrm{C}$ and D significant similarities in properties, this might be attributed to the very small percentages $(5 \%$ and $10 \%$ ) of ethanol that was added to gasoline. However, the import of the blending will be felt more when analyzing its effects on engine performance and emissions.

\section{B. Results of engine performance tests}

The Engine Performance tests were carried out at 800rpm, 100rpm, 1200rpm, and 1400rpm, and at each speed, the Torque, fuel consumption, and the exhaust gas temperature were read on the test bed. However other performance criteria were calculated from these parameters as well as data from the results of the physicochemical analysis, and the results are tabulated in Tables II, III, and IV for samples B, C, and D respectively. 
TABLE II: PERFORMANCE OF SAMPLE B ON THE ENGINE

\begin{tabular}{cccccc}
\hline \hline $\begin{array}{c}\text { Speed } \\
(\mathrm{rpm})\end{array}$ & $\begin{array}{c}\text { Torque } \\
(\mathrm{Nm})\end{array}$ & $\begin{array}{c}\text { Exhaust } \\
\text { Temp. }\left({ }^{\circ} \mathrm{C}\right)\end{array}$ & $\begin{array}{c}\text { Brake Power } \\
(\mathrm{KW})\end{array}$ & $\begin{array}{c}\text { BSFC } \\
(\mathrm{Kg} / \mathrm{Kw} / \mathrm{h})\end{array}$ & $\begin{array}{c}\text { Thermal } \\
\text { Efficiency }(\%)\end{array}$ \\
\hline 800 & 5.49 & 110 & 0.46 & 540.01 & 9.3 \\
1000 & 4.67 & 130 & 0.49 & 489.9 & 9.8 \\
1200 & 4.05 & 150 & 0.51 & 444.4 & 10.25 \\
1400 & 3.61 & 170 & 0.53 & 400.7 & 10.6 \\
\hline \hline
\end{tabular}

TABLE III: PERFORMANCE OF SAMPLE C ON THE ENGINE

\begin{tabular}{cccccc}
\hline \hline $\begin{array}{c}\text { Speed } \\
(\mathrm{rpm})\end{array}$ & $\begin{array}{c}\text { Torque } \\
(\mathrm{Nm})\end{array}$ & $\begin{array}{c}\text { Exhaust } \\
\text { Temp. }\left({ }^{\circ} \mathrm{C}\right)\end{array}$ & $\begin{array}{c}\text { Brake Power } \\
(\mathrm{KW})\end{array}$ & $\begin{array}{c}\text { BSFC } \\
(\mathrm{Kg} / \mathrm{Kw} / \mathrm{h})\end{array}$ & $\begin{array}{c}\text { Thermal } \\
\text { Efficiency }(\%)\end{array}$ \\
\hline 800 & 5.56 & 120 & 0.46 & 508.7 & 9.2 \\
1000 & 4.63 & 140 & 0.48 & 477.3 & 9.6 \\
1200 & 4.17 & 160 & 0.52 & 423.15 & 10.1 \\
1400 & 3.70 & 180 & 0.54 & 387.24 & 10.9 \\
\hline \hline
\end{tabular}

TABLE IV: PERFORMANCE OF SAMPLE D ON THE ENGINE

\begin{tabular}{cccccc}
\hline \hline $\begin{array}{c}\text { Speed } \\
(\mathrm{rpm})\end{array}$ & $\begin{array}{c}\text { Torque } \\
(\mathrm{Nm})\end{array}$ & $\begin{array}{c}\text { Exhaust } \\
\text { Temp. }\left({ }^{\circ} \mathrm{C}\right)\end{array}$ & $\begin{array}{c}\text { Brake Power } \\
(\mathrm{KW})\end{array}$ & $\begin{array}{c}\text { BSFC } \\
(\mathrm{Kg} / \mathrm{Kw} / \mathrm{h})\end{array}$ & $\begin{array}{c}\text { Thermal } \\
\text { Efficiency }(\%)\end{array}$ \\
\hline 800 & 5.96 & 160 & 0.47 & 471.5 & 9.4 \\
1000 & 4.67 & 180 & 0.49 & 449.8 & 9.8 \\
1200 & 4.21 & 200 & 0.53 & 402.7 & 10.6 \\
1400 & 3.95 & 210 & 0.58 & 355.2 & 11.6 \\
\hline \hline
\end{tabular}

\section{Torque}

The effect of addition of different percentages of ethanol to gasoline at different speeds on engine torque is as shown in Fig. 4. It can be deduced that sample D produced the highest torque followed by sample $\mathrm{C}$ and sample $\mathrm{B}$ in that other. Conclusively, the higher the percentage of ethanol addition the higher the torque produced within the engine speed of $800 \mathrm{rpm}$ to $1400 \mathrm{rpm}$. This showed that one way to improve the torque generated by SI engine is to blend the gasoline with ethanol, however, the percentage of ethanol should be not be above $10 \%$.. The brake torque of gasoline (sample B) was lower than that of sample $\mathrm{C}$ and $\mathrm{D}$, but will result into better antiknock tendency and improved combustion.

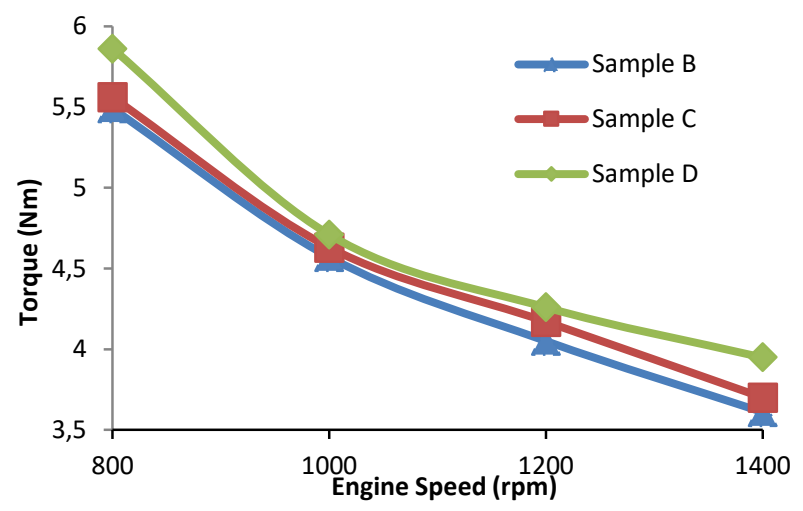

Fig. 4. Torque (Nm) vs. Engine Speed (rpm)

\section{Brake Power}

The brake power of the engine increased with engine speed as shown in Fig. 5, sample D presented the best bake power across the speed range. Sample B produced better brake power at 100rpm than sample $C$ but as the engine speed increases, sample $\mathrm{C}$ produced better brake power than sample B. This showed that the addition of ethanol to gasoline enhance the brake power of the engine.

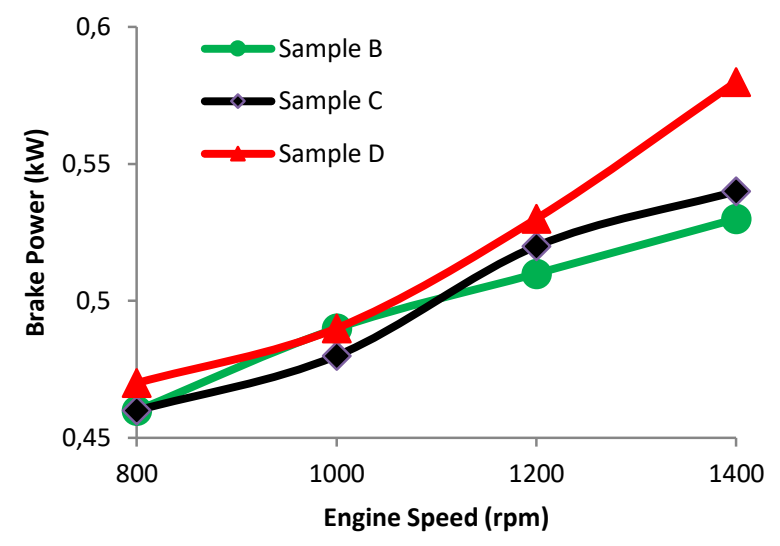

Fig. 5. Brake Power (kW) vs. Engine Speed (rpm)

\section{E. Exhaust Temperature}

Variations in the exhaust gas temperature at different speeds of the engine are as presented in Fig. 6. There is an increase in exhaust gas temperature with rise in the speed of the engine. This is true for stationary, air cooled engine due to absence of either water of air to cool the engine Moreover, there is an average decrease in exhaust gas temperature as compared to pure gasoline are $6.89 \%$ and $13.97 \%$ in sample $\mathrm{C}$, and sample $\mathrm{D}$ respectively. Conclusively, addition of ethanol to gasoline increases the exhaust gas temperature of the engine considerably.

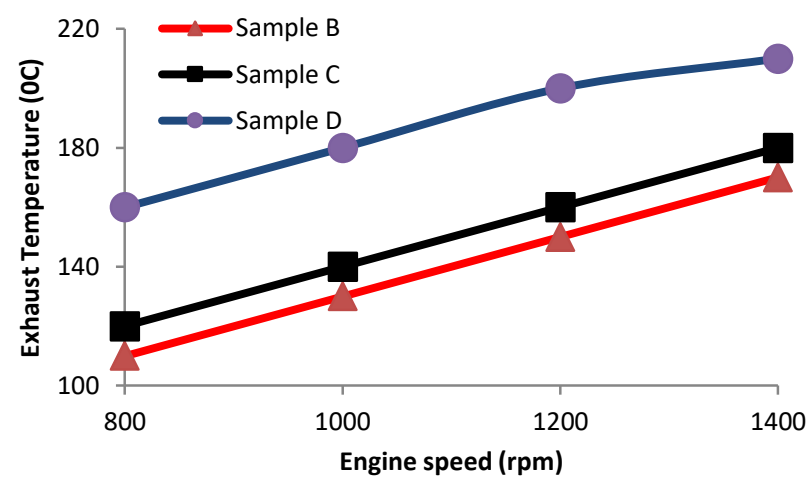

Fig. 6: Exhaust Temperature (\%) vs. Engine Speed (rpm) 


\section{F. Brake Specific Fuel Consumption}

Brake Specific Fuel consumption is a measure of how much fuel is consumed in one hour to produce one kilowatt brake power at the engine shaft. The importance of fuel consumption cannot be over emphasized in this study as it gives the amount of energy produced for every unit of fuel consumed. As highlighted in Fig.7, It is noticed that BSFC reduces as the percentage of ethanol rises to $10 \%$. Furthermore, the BSFC reduces with the increase in engine speed. In addition, there is a small change in the BSFC via pure gasoline and ethanol/gasoline blend, particularly at high engine speed. However, it is to be expected outcome of engines at higher speeds [9].

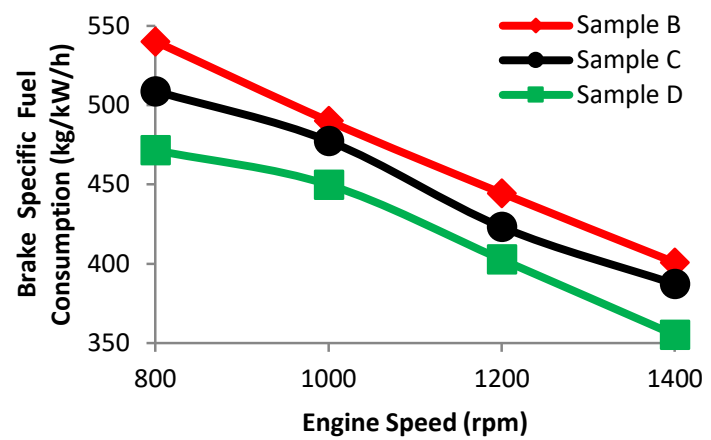

Fig. 7. Brake Specific Fuel Consumption (kg/kW/h) vs. Engine Speed (rpm)

\section{G. Thermal Efficiency}

The variation of engine speeds with thermal efficiency is shown in Fig. 8. It was observed that increase in engine speed resulted in corresponding increase in the thermal efficiency, where the quantity of air increase due to the consequence of choking in the induction system [9]. Furthermore, Fig. 8 illustrates a rise in the thermal efficiency as the percentage of ethanol in fuel blends increased to $5 \%$. This can be attributed to the increase of the charge temperature at the end of the induction process.

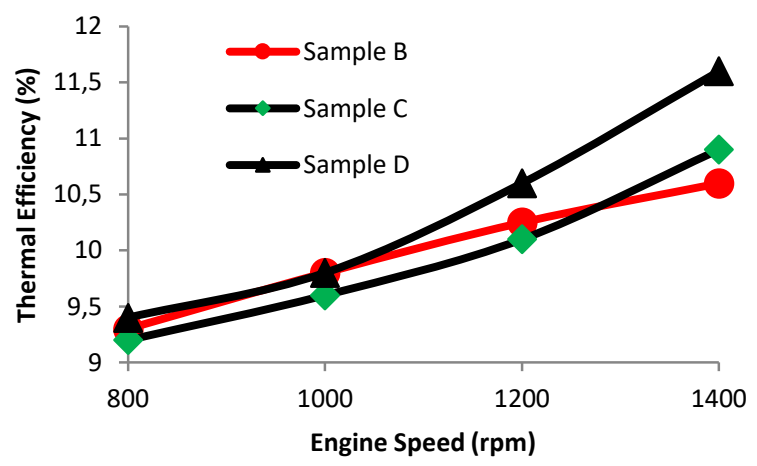

Fig. 8: Thermal Efficiency (\%) vs. Engine Speed (rpm)

\section{H. Results of emission test}

The result of emission analysis of running samples B, C, and D on spark ignition engine at no load is as shown in Table V. Five gases were analyzed, namely Carbon Monoxide (CO), Carbon Dioxide, $\left(\mathrm{CO}_{2}\right)$, Oxygen $\left(\mathrm{O}_{2}\right)$, Hydrocarbon (HC), and Nitrogen Oxide, (NOx). The variations of each emission are shown in Figs. 9 to 12.
TABLE V: EMISSION RESULT ON NO LOAD

\begin{tabular}{cccc}
\hline \hline Exhaust Gases & Sample B & Sample C & Sample D \\
\hline $\mathrm{CO}(\%)$ & 3.15 & 1.26 & 0.73 \\
$\mathrm{CO}_{2}(\%)$ & 6.24 & 6.07 & 4.99 \\
$\mathrm{HC}(\mathrm{ppm})$ & 173 & 304 & 1716 \\
$\mathrm{NO}_{\mathrm{X}}(\mathrm{ppm})$ & 49 & 51 & 85 \\
$\lambda$ & 0.50 & 3.01 & 0.50 \\
\hline \hline
\end{tabular}

\section{Carbon dioxide}

The percentage of Carbon dioxide $\left(\mathrm{CO}_{2}\right)$ emission for the various samples is shown in Fig. 9. Sample B present the highest percentage of $\mathrm{CO}_{2}$ emission of $6.24 \%$ followed by sample C of $6.07 \%$ and sample D of $4.99 \%$. The addition of gasoline resulted in the reduction in the percentage of $\mathrm{CO}_{2}$ in the emission and makes the mixture more environmental friendly. Though the result showed that there was complete combustion.

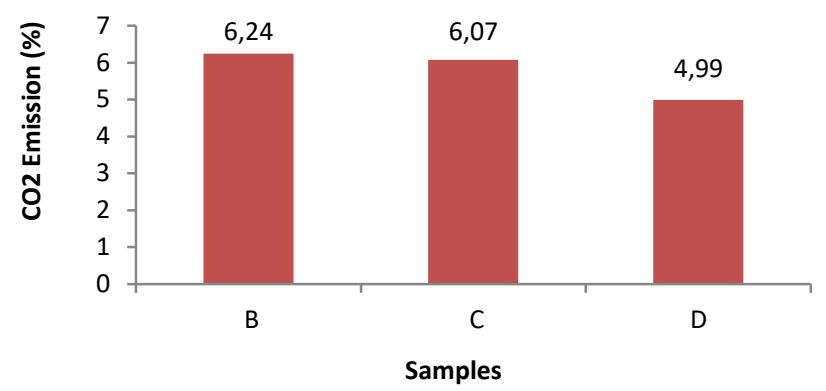

Fig. 9. Carbon dioxide emission of samples

\section{J. Hydrocarbon}

Hydrocarbons (HC) are an emission resulting from the release of unburned fuel into the atmosphere. Hydrocarbon emissions are usually caused by incomplete combustion or by fuel evaporation. As shown in Fig. 10, $\mathrm{HC}$ emission increases with addition of ethanol to gasoline. The emission is reduced and this can be attributed to a better combustion rate. However, this is ascribed to the variation of the stoichiometric air-fuel ratio of the ethanol blends with the actual air-fuel ratio of the ethanol blends as a result of the increase in oxygen content in the ethanol [9].

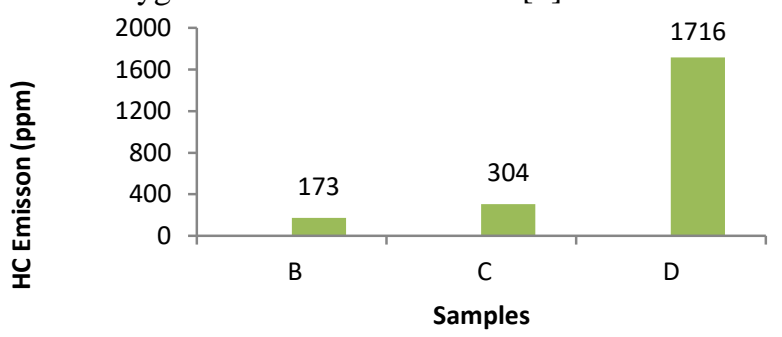

Fig. 10. Hydrocarbon emission of samples

\section{K. Carbon monoxide}

Carbon monoxide $(\mathrm{CO})$ exists only in engine exhaust. $\mathrm{CO}$ is an extremely toxic emission resulting from the release of partially burned fuel. Since CO emission is as a result of incomplete combustion, the way to eliminate $\mathrm{CO}$ emission is to ensure complete combustion in our engines always particularly during idling when $\mathrm{CO}$ emission has been found to be high. Though the addition of $5 \%$ ethanol and $10 \%$ ethanol to gasoline respectively reduce the $\mathrm{CO}$ emission from $3.15 \%$ to $1.26 \%$ and $0.73 \%$ respectively as shown in 
Fig. 11, these figures are still higher than the reasonable and acceptable target of $0.5 \%$.

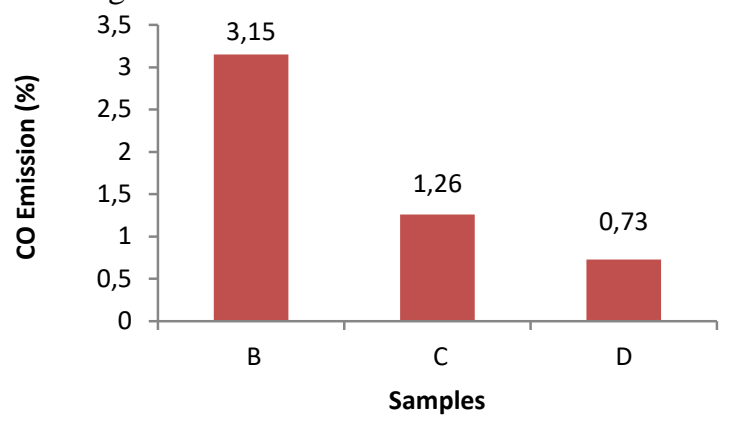

Fig. 11. Carbon monoxide emission of samples

\section{Oxides of Nitrogen}

Oxides of Nitrogen $\left(\mathrm{NO}_{\mathrm{x}}\right)$ are emissions produced by high temperatures during process of combustion. With enough heat, above $1370^{\circ} \mathrm{C}$, nitrogen and oxygen in the air-fuel mixture combine to form $\mathrm{NO}_{\mathrm{x}}$ emissions. Therefore, high temperature and availability of oxygen are the two main conditions for the formation of NOx. As shown in Fig. 12, the NOx emission increased significantly with the addition of ethanol to gasoline.

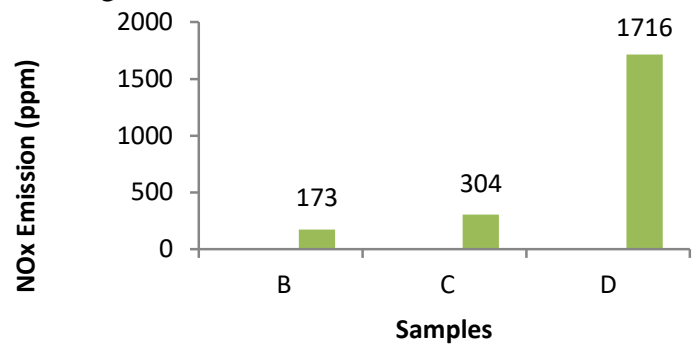

Fig. 12. Oxides of Nitrogen emission of samples

\section{CONCLUSION}

The effect of using gasoline-ethanol blends on SI engine has been investigated in this research. The research comprises the blending of various percentage of ethanol with gasoline, determining the physicochemical properties, using the fuel samples to run and IC engine, determining the performance characteristics of the engine at specified speeds and carrying out an exhaust gas analysis when using the samples to run an IC engine at no load. The results showed that blending gasoline with ethanol can increase torque, thermal efficiency and exhaust gas temperature, while it decreases the specific fuel consumption. The $10 \%$ volume ethanol in fuel blend indicates the best results for all measured parameters at all the engine speeds considered.

\section{ACKNOWLEDGMENT}

The authors thank Agbaje Eniola Tosin and Awoleye Odunayo for their assistance in collating data for this research. We also appreciate the authorities of the Federal University of Technology, Akure, Nigeria and Covenant University, Ota, Nigeria, for permission to use their physiochemical analysis equipment and the SI engine test bed, TD200, respectively.

\section{REFERENCES}

[1] S.L Ashish, and M.J Deshmukh, (2012). Performance and Emission Characteristics of SI Engine using LPG-Ethanol Blends: A Review. International Journal of Emerging Technology and Advanced Engineering (IJETAE). 2(10). 146-152 Available: http://www.ijetae.com.

[2] R.A Gorse. The effects of methanol/gasoline blends on automobile emissions. SAE Paper 920327. 1992.

[3] Alexandrian, M., Schwalm, M., (1992). Comparison of ethanol and gasoline as automotive fuels. ASME papers 92-WA/ DE-15.

[4] Chandler, K., Whalen, M., Westhoven, J. Final result from the state of Ohio ethanol-fueled light-duty fleet deployment project. 1998. SAE Paper 982531.

[5] Hsieh, Wei-Dong, Chen, Rong-Hong; Wu, Tsung-Lin; Lin, Ta-Hui. Engine performance and pollutant emission of an SI engine using ethanol-gasoline blended fuels. Atmospheric Environment, 36(3) 2002. pp. 403-410.

[6] A.A., Abdel-Rahman, M.M Osman. Experimental investigation on varying the compression ratio of SI engine working under different ethanol-gasoline fuel blends. International Journal of Energy Research 21, 1997. pp 31-40.

[7] R.M Bata., A.C. Elord, and R.W Rice . Emissions from IC engines fueled with alcohol-gasoline blends: a literature review. Transactions of the ASME 111, 1989. pp 424-431.

[8] Mustafa Koc, Yakup Sekmen, Tolga Topgul and Huseyin Serdar Yucesu. The effect of ethanol-unleaded gasoline blends on engine performance and exhaust emission in a spark-ignition engine. Renewable Energy 34, 2009. pp 2101-2106.

[9] M. Attalla, A. M .A. Soliman and Mahmoud A. Torky. (2013). Engine Performance and Exhaust Emissions of an SI Engine Using Acetic Acid, Ethanol, and Gasoline Blended Fuel. 13(5). pp 93Available: http://ijens.org/Vol_13_I_05/1310305-8989-IJETIJENS.pdf?cv=1, 